\title{
ASO Author Reflections: Validation Based on Low-Volume Metastasis of the Sentinel Lymph Node Biopsy in Early-Stage Cervical Cancer
}

\author{
Benedetta Guani, $\mathrm{MD}^{1,2}$ (D), and Patrice Mathevet, $\mathrm{PhD}, \mathrm{MD}^{1,2}$ \\ ${ }^{1}$ Department of Gynecology, CHUV, Lausanne, Switzerland; ${ }^{2}$ Faculty of Medicine, UNIL, Lausanne, Switzerland
}

\section{PAST}

Sentinel lymph nodes normally are examined with ultrastaging, and non-sentinel nodes usually are examined only with routine technique. Low-volume metastasis (micrometastasis and isolated tumor cells) can be missed by classical pathologic analysis. For ability to consider the sentinel node technique as safe, clinicians must be sure that its negative predictive value (NPV) is $100 \%$.

\section{PRESENT}

To validate the sentinel lymph node technique from the lowvolume metastasis point of view, the "Histopathological validation of sentinel lymph nodes study", ${ }^{1}$ currently in press, included an ultra-staging examination of all nodes, sentinel nodes, and non-sentinel nodes of all Senticol 1 patients. ${ }^{2}$ To date, the discovery of these low-volume metastases can imply therapeutic decisions that can modify the patient's management even if their clinical significance remains uncertain. This study ${ }^{1}$ can confirm that the NPV is $100 \%$ for optimal mapping with bilateral detection, which also is the low-volume metastasis point of view.

\section{FUTURE}

The sentinel node technique is a safe technique. The future lies in standard use of the sentinel node technique for early-stage cervical cancer patients instead of

(C) The Author(s) 2020

First Received: 26 October 2020

Accepted: 27 October 2020;

Published Online: 20 November 2020

B. Guani, MD

e-mail: benedetta.guani@hotmail.it lymphadenectomy. Clinicians are awaiting the results of Senticol $3^{3}$ for definitive validation of this technique.

FUNDING Open access funding provided by University of Lausanne.

DISCLOSURE There are no conflicts of interest.

OPEN ACCESS This article is licensed under a Creative Commons Attribution 4.0 International License, which permits use, sharing, adaptation, distribution and reproduction in any medium or format, as long as you give appropriate credit to the original author(s) and the source, provide a link to the Creative Commons licence, and indicate if changes were made. The images or other third party material in this article are included in the article's Creative Commons licence, unless indicated otherwise in a credit line to the material. If material is not included in the article's Creative Commons licence and your intended use is not permitted by statutory regulation or exceeds the permitted use, you will need to obtain permission directly from the copyright holder. To view a copy of this licence, visit http://creativecommons.org/licenses/by/4.0/.

\section{REFERENCES}

1. Mathevet P, Guani B, Ciobanu A, et al. Histopathologic validation of the sentinel node technique in early-stage cervical cancer patients. Ann Surg Oncol. 2020. https://doi.org/10.1245/s10434020-09328-2.

2. Lécuru F, Mathevet P, Querleu D, et al. Bilateral negative sentinel nodes accurately predict absence of lymph node metastasis in early cervical cancer: results of the SENTICOL study. J Clin Oncol. 2011;29:1686-91.

3. Lecuru F, McCormack M, Hillemanns P, et al. SENTICOL III: an international validation study of sentinel node biopsy in early cervical cancer: a GINECO, ENGOT, GCIG and multicenter study. Int J Gynecol Cancer. 2019;29:829-34.

Publisher's Note Springer Nature remains neutral with regard to jurisdictional claims in published maps and institutional affiliations. 